\title{
Factors Impeding Effective Crop Production in Ethiopia
}

\author{
Bulti Merga ${ }^{1} \&$ Jema Haji ${ }^{2}$ \\ ${ }^{1}$ School Plant Sciences, Haramaya University, Ethiopia \\ ${ }^{2}$ School of Agro-economics and Agribusiness, Haramaya University, Ethiopia \\ Correspondence: Bulti Merga, School Plant Sciences, Haramaya University, Ethiopia. E-mail: \\ bultimerga@gmail.com
}

Received: January 26, 2019

Accepted: May 2, 2019 Online Published: July 15, 2019

doi:10.5539/jas.v11n10p98

URL: https://doi.org/10.5539/jas.v11n10p98

\begin{abstract}
In the Ethiopia crop agriculture, pillar in balancing the food diet of the majority people, as a whole and the cereals specifically is facing serious and vast challenges which in turn affect the supply of food grains. Various research institutes in Ethiopia have revealed several factors which affect crop production over the past three decades, but their findings are not synthesized into a whole and difficult to access as such. This study attempts to review various existing research findings and present them holistically. The most common factors are lack of more recently introduced improved seeds, initial capital for investment, loss of cropland, labor, pesticides, invasive alien species, farm storage techniques, methods of small scale irrigation, and religious and cultural challenges. Thorough understanding these constraints, researchers and policy makers can make useful recommendations to crop growers' on farm improvement system and not on how to devastate well designed sustainable crop production systems. Succinct and collated scientific information would help to shade light on the best standards to overcome most factors affecting crop production and enhance the productivity and quality of crops. Moreover, this paper offers more implications and recommendations for various stakeholders in Ethiopian and similar contexts.
\end{abstract}

Keywords: agriculture, production, factors, farm households

\section{Introduction}

Over the world food grain supply is considerably less than the demand of the majority of people. The population of Ethiopia is projected to undergo the rapid growth and double while the GDP is expected to show a substantial increase from below USD 700 to above USD 5500 within the range of 2015 to 2050 year (UNPF, 2017). Even though, the population and GDP per capita of Ethiopia is increasing in a rapid manner the agricultural productivity is still by far less that other countries over the world. More than 12 million households, or 70 percent of the population in Ethiopia, keep cattle as a source of income, food, draft power, insurance and savings, social capital and other goods and services (FAO, 2018). The vast majority of households that depend on cattle are in mixed-crop livestock systems, with cattle contributing over 30 percent to total household income. In the pastoral/agro-pastoral system, nearly 50 percent of household income comes from cattle production. A large share of households (41 to 95 percent, depending on production systems) uses cattle dung and draft power, thereby further supporting their livelihoods (FAO, 2018). Also, on average, 42 percent of the Ethiopian population consumes dairy products on a regular basis. Per-capita milk consumption is 576 grams per week (FAO, 2018). A cultivating framework is delineated as a populace of individual homestead frameworks that have commonly comparable asset bases, undertaking designs, house employments and requirements, and that comparative improvement ways and mediations would be material (FAO, 2018). With persistently expanding interest for nourishment joined by the imperatives of environmental change and the accessibility and nature of soil and water, the world's agriculturists are tested to deliver more sustenance per hectare with less water, and with less agrochemical inputs if conceivable (Adhikari et al., 2018). Diversification of agriculture, both as far as harvests developed and the farming framework itself (for example intercropping), could fundamentally enhance farming versatility, yet the use of genomics to a far more extensive scope of yields is likewise required to bridle the maximum capacity of a large number of these species, just as for the staple harvests which will keep on speaking to the principal focal point of breeding research (Fridman \& Zamir, 2012; Abberton et al., 2016). In growing nations, invasive alien species threaten the smallholder farmer production and the food security of subsistence growers, but monetary impacts are broadly below-said (Pratt et al., 2017). 
Crop production is the premise of all subsistence farming in many portions of Ethiopia on rain fed system and it accounts for more than $95 \%$ of land vicinity cultivated yearly. In general, farming system which employs mixed animal and crop production is important and preferable to improve and sustain the livelihood of Ethiopian farmers. A typical farming household in the semiarid area occupied a small portion of land (Pingali, 2006). The settlements of most Ethiopians reveal that the majority of people are living in rural areas where the homestead and the farming site located at the same place. Hence, subsistence and rain fed agricultural production based on the economy is the fundamental means of improving the livelihood of the majority of the people. One of the determinants of improved crop seed adoption is the size of the family that the fast adopter of technology and risk takers are those who have low family size where adequate data about advancement found and also committed to agriculture (Sánchez-Toledano et al., 2018).

The stumbling block to enhancing the commitment of agriculture in Ethiopia over the normal of sub-Saharan Africa is that some crops cultivated during the rainy season are subject to low spares of vegetation stage in respect to their duration. This causes shrouding at vegetation stage, which makes the crops to have little effect on an areal performance of the plant (Kindness \& Gordon, 2001).

Ethiopia's crop agriculture is mind boggling; including significant variety in crops developed the nation over various districts and ecologies (IFPRI, 2011). Five noteworthy cereals; teff, wheat, maize, sorghum, and barley are the center of Ethiopia's agriculture and nourishment economy, representing around three-fourths of the absolute zone developed, 29 percent of farming total national output (GDP) in 2005/06 (14 percent of complete GDP), and 64 percent of calories expended (FAO different years) (Se et al., 2013). Nonetheless, most practices of present day farming, for example monocultures, improved crop cultivars, and substantial utilization of Agrochemicals for fertilization and pest management, prompted a rearrangements of the segments of agricultural systems and to lost biodiversity (Abdulai, 2016). There has been generous increase in cereal crop production as far as cultivated land increase since 2000, yet yields are low by worldwide standards, and generally speaking the productivity is exceedingly prone to climate stuns, especially dry seasons. Along these lines, raising productivity levels and lessening their inconstancy are fundamental parts of enhancing sustenance security in Ethiopia, both to help guarantee sufficient nourishment accessibility and to increment rustic family unit wages (IFPRI, 2011). Hence, this paper attempts to critically and holistically review various studies and explore the major factors that affect crop production in Ethiopia.

\section{Conceptual and Theoretical Frame Work}

\subsection{Concept}

Crop designates cereal crop, crop pulses, oil seeds, horticulture crop, coffee, enset, khat, sugar cane, cotton, tobacco and other crops produced for food, making drinks, stimulation and fabrics or cloth (CSA, 2014). Crop production is the process of best parent selection, seed collection, suitable land selection, sowing, growing and harvesting the above and below ground crop parts for households consumption and sale for foreign and domestic market. Cereal crop harvested from the months of September to February is called a Meher season crop in Amharic while that harvested from the months of March to the last days of August is known as Belg season crop (CSA, 2014).

The production function is the technical relationship between inputs and outputs (Ushamutu, 2012). It indicates the maximum amount of outputs that can be produced with alternate amounts of variable inputs used in combination with one or more fixed input under a given state of technology. Moreover, it allows explaining the output value generated either by the whole economic based or drivers' combination of factors determining the existing technology (Kuhn, 2010). A factor of production refers to an aggregate of nature (such as water, minerals and forests), human limit (both mental and physical) and a wide range of man-made guides to advance production, (devices, machines and structures). They are otherwise called resource or inputs. Factors of production can be classified into land, labor and management in agricultural crop production and challenge studies for solution (Crawford et al., 2003).

Ethiopia's food crop supply quantity and consumption of products per year has been shown constant trend for the last one and a half decades (Figure 1). Even though, the food crops production quantity has revealed the substantial increase the Ethiopian population is also undergoes rapid growth. Additionally, the supply of food cereal crops is projected to stay in constant level with equivalent food crop consumption per year from the vast majority of the Ethiopian people. Hence, the quantity of food crop production in yield should be greater than the growth rate of Ethiopian population to feed the coming generations and sustain their livelihood, which in turn increase the economy of the country and reduce the poverty. 


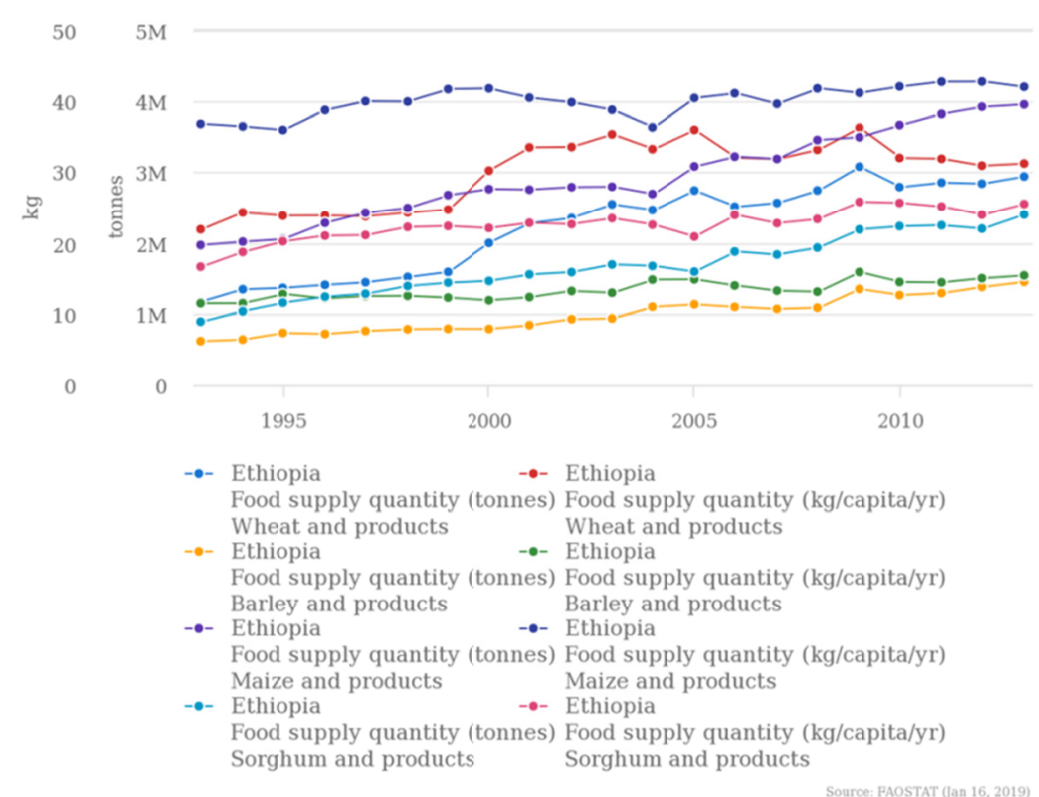

Figure 1. Ethiopian food crops supply

Source: FAOSTAT (January 16, 2019). Retrieved from http://www.fao.org/faostat/en/\#compare

\subsection{Theoretical Frame Work}

\subsubsection{Agricultural Production and Global Challenges}

The difficulties for worldwide agriculture in the $21^{\text {st }}$ century' are to create $70 \%$ more sustenance by 2050 to encourage an anticipated increment of population with actualizing progressively supportable techniques and reacting to climate change on the earth. Front climate change and its impact on production clearly suggest the need to address problems; variations in the availability of water (lack or excess thereof), the reduction in agricultural productivity and the need for low impact technologies to reduce the emission of greenhouse gases. Moreover, the interest of the majority people is expected to shift from cereals to the product of cattle. Much worry about sustaining the world in 2050 identified with the moderate increment from the side of major food crop edits in the course of the last multi decade demonstrated that yield is considered as the real course to take care of future worldwide nourishment demand through expanded potential field (Kindness \& Gordon, 2001).

\subsubsection{Overview of Agriculture and Crop Production in Ethiopia}

Agricultural production dominates the country to the extent that little progress can be made, unless agriculture is affected directly. Agriculture, which acts as a pillar to balance the economic growth and the food demand, in Ethiopia is subsistence that exists due to the major cereal crop cultivated in the country. Teff, wheat, maize, sorghum, and barley cereal crop are produced in many parts of the country in spite of the variation in quantity of production across the regions (CSA, 2014). Ethiopia recognizes two dominant agricultural systems which are the mixed agriculture of the highland in which both crops and livestock production are integrated, and pastoralist in the lowland. Commercial agriculture using the river basin such as the Awash Basin is the infancy status of irrigation system in Ethiopia which considered as a current phenomenon (Getahun, 1978). The land area which is used for cereal crop production continued almost in constant trend even though ups and down happen in some years while the productivity yield reveals the substantial increase in Ethiopia for the last 15 cropping seasons (Figure 2). 


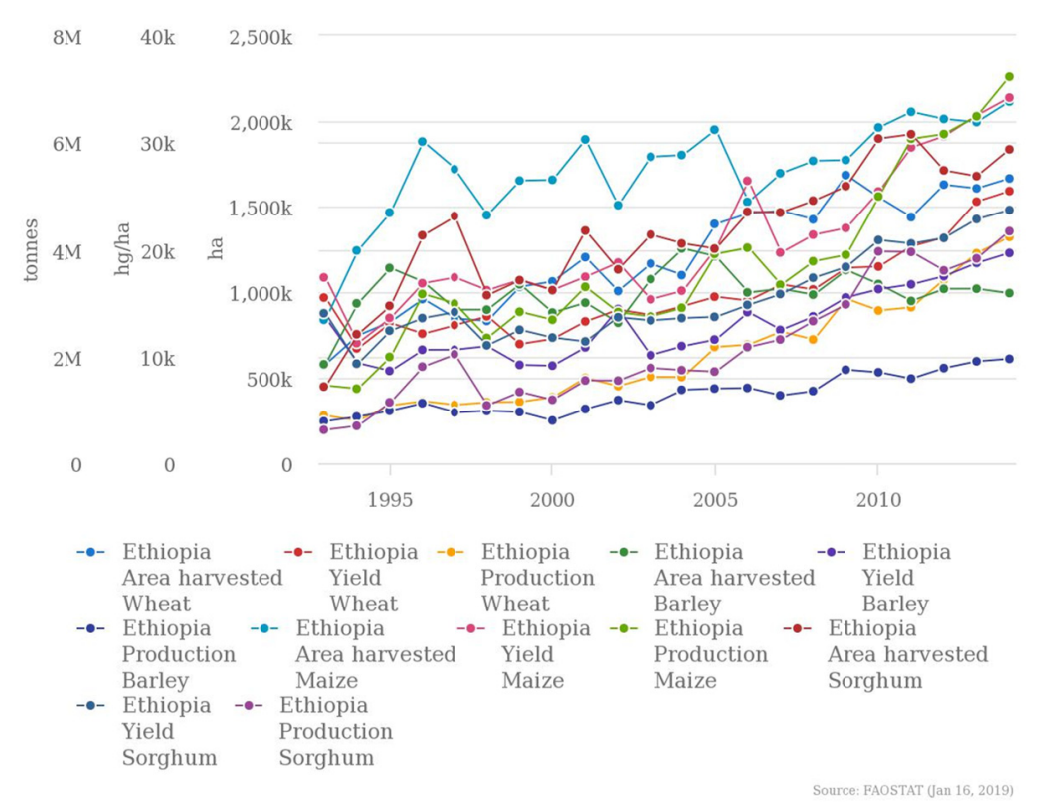

Figure 2. Ethiopian area harvested and cereal crop yield production

Source: FAOSTAT (January 16, 2019). Retrieved from http://www.fao.org/faostat/en/\#compare

\section{Factors of Crop Production Based on Production Function}

\subsection{Land and Crop Production}

In Ethiopia, land policy has long been considered as a major obstacle to economic development, hampering production, productivity and income of rural farm households. Economists and donors present a range of possible policy changes to improve productivity and efficiency, including privatization of land, liberalization of land rental markets and instituting secure, long-term and transferable use rights. They further argue that public ownership of land hinders farmers from making long term investments in their land leading to land degradation, mainly due to increased tenure insecurity. On the other hand, private ownership of land by the rural financial income has been hotly pursued but problem plagued undertaking. No other concern than eviction of the rural poor from their land by the elite has an acute effect on the status quo to be unresolved soon.

Agricultural researchers in Ethiopia agree that crop production has increased mainly as a result of crop grown area. In Ethiopia farm households who have a high number of children's needs higher food grains for consumption and young labor living with parent foreseeing land for employment creation.

The area of agricultural land, cropland and arable land has been following the slight increase trend while country area and the total free land area do not change in the last 15 years (Figure 3). 


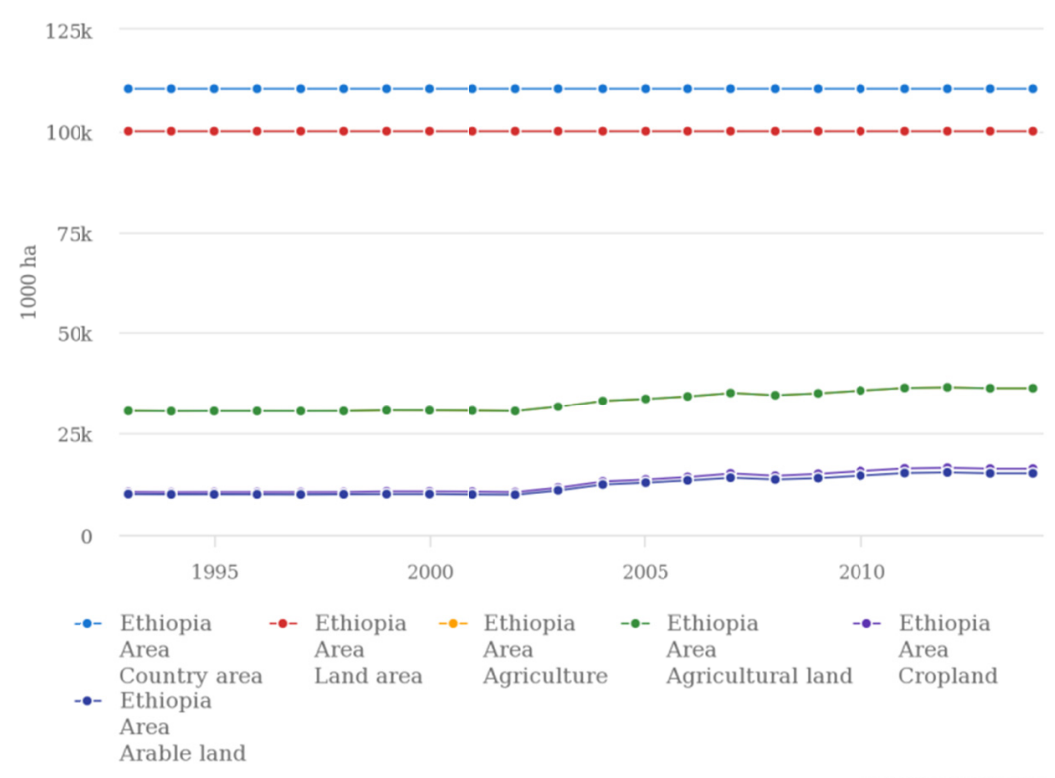

Figure 3. Ethiopian country, arable land, agriculture, agricultural and cropland area

Source: FAOSTAT (January 16, 2019). Retrieved from http://www.fao.org/faostat/en/\#compare

\subsection{Labor in Crop Production}

The homesteads families units in country zones of developing nations more often than not apportion their time among claim cultivate work and off farm action. Farm labor is a noteworthy wellspring of business open door for the work compel in provincial zone of Ethiopia. The accessibility of openings for work in the casual segment not just helps cultivate family units moderate negative outcomes of land misfortune, yet in addition open another opportunity for them to change and differentiate their employments (Tuyen et al., 2014). As in most developing countries, the structure of labor compel work in Ethiopia is principally made out of stable measure of unpaid family work and independent work (CSA, 2005).

Low farm labor supply may lead to low farm productivity in a situation which has been considered as a major problem, especially in some developing countries. Labor productivity is an important source of long term growth and its impostures of what farmers and workers get in return for their efforts (time and management skills), and the growth rate of labor productivity level. However, it has shown a dramatic increase (CSA, 2008).

\subsection{Capital Level of Investment as a Factor of Crop Production}

The sustainable intensification of agricultural systems offers synergistic opportunities for the co-production of agricultural and natural capital outcomes (Pretty et al., 2018). Different literature provided evidence that indicate, because insurance, credit and saving markets are typically not well developed, people in rural areas of developing countries, mostly rely on their own resources (e.g., saving, natural capital assets, labor and land combined with social capital) for more investments and manage risks (Yesuf \& Bluffstone, 2009; Fafchamps \& Gubert, 2007; Chetty \& Looney, 2006; Narayan, 2004). As a resource factor livestock ownership might affect crop production both positively and negatively. In Ethiopia, livestock endowment has dual influence on crop production since the latter is expected to be supplemented by animal production (Asefa, 2011). In this way, household who possess livestock can get more advantages.

\subsection{Religious and Cultural Factors of Crop Production}

Farmers are supposed to produce everything that is required for themselves and others (Mesfin, 1984). However, having long and deep-rooted religious and cultural practices, the bulk of Ethiopian farmers are the most serious factors for low agricultural productivity. These central and religious practices and institutions negatively affect the overall subsistence agricultural production systems.

\subsection{Invasive Alien Weed Species}

Invasive alien weed species, insect pests and diseases are other global threats to crop grain production which cause yield reduction or even elimination that results in food insecurity. The first three to five weeks after 
planting are critical stages in weed infestation during crop cultivation. If our weed control program is to not par during this period, no amount of herbicide or cultivation saves the yield from losses and this makes farmers hopeless to cultivate for next cropping seasons. Crop rotation, herbicide selection, identifying emerging weed threats, good residue distribution, and getting a good crop stand are all parts of good weed control. The lesser extent, let's put insect control and disease protection in this same category.

Crop yield loss can occur due to many factors, such as system of crop cultivation, crop variety, plant population, fertilizer applied, duration and time of weed infestation, weed species and amount of weed grown in a farming area. The comparison between controlled and uncontrolled weed plot overstate the additional benefit of controlling weeds. More elastics approach compared the added benefit from additional limited available data showed that crop production loss can reach 30-40\% for field that are poorly weeded (Pingali, 2006). Intercropping systems often exhibit less crop damage associated with insect and plant pathogen attacks, and they provide weed control.

There are many invasive weed species in Ethiopia, among other, the most agricultural and arable land invaded includes striga, orobanche, cuscuta, parthenium hysterophorus and Prosopis Juliflora. The loss of food crop yield through invasive weed is assumed to be from $25 \%$ to $30 \%$ in Ethiopia due to less management system and low income of farmers, which hinder them from buying herbicides to control weed infestation in farm land (Figure 4).

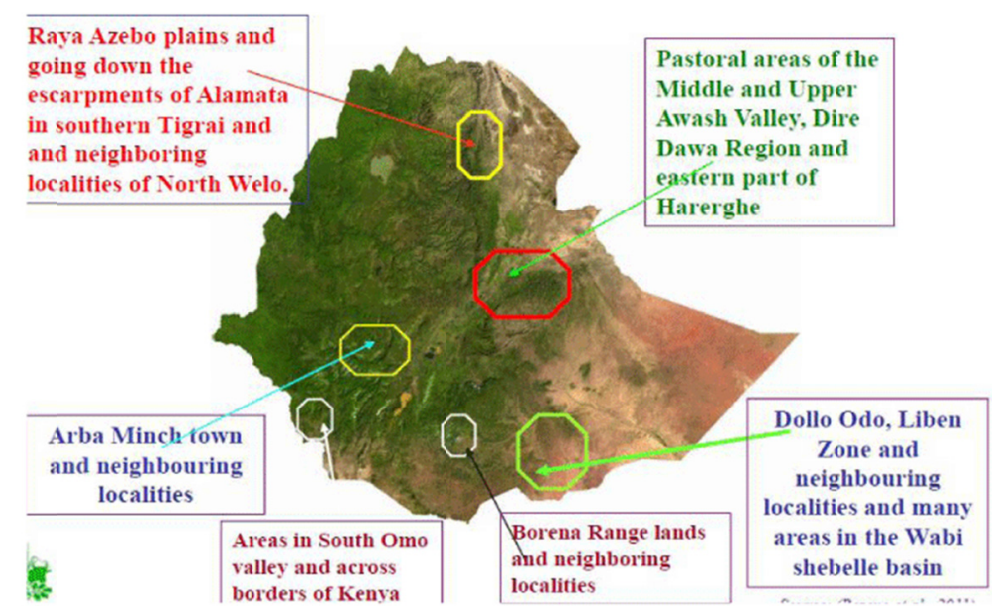

Figure 4. Distribution map of Prosopis Juliflora in Ethiopia (Rezene et al., 2011)

\subsection{Irrigation Practice as a Factor of Crop Production}

The concept of irrigated nutrient practice involves the use of various inorganic, organic and biological sources and mobiliser of plant nutrient. The major components are fertilizers, organic manure, green manure, crop residue and biofertilizers. In crop such as rice, wheat and maize, irrigation system indicated high efficiency use of green manure $\mathrm{N}_{2}$ fertilizer (Hussai \& Hanjira, 2004). Research showed that with increasing irrigation intervals and reducing soil moisture in the reproductive stages the grain filling period decreases with the crop grain weight loss. Hence, this can be concluded that delay of irrigation has more of influence on 1000-grain weight than nitrogen and zinc application on wheat crop (Parsai et al., 2016). Maize requires water in particular definite quantities for its optimal growth, and excessive or shortage of water could retard growth and the crop yields will be lower eventually. With this, the grain yield is affected by irrigation and is obtained highest at complete restitution of evapotranspiration (Rakesh \& Rajikumar, 2018).

\subsection{Tillage Operation}

Deep ploughing has great advantage for perennial weed control and conservation of moisture under dry land condition. The result of the experiment (Batie, 1989) clearly indicated the beneficial effect of deep ploughing $(30-40 \mathrm{~cm})$ over shallow $(10-12 \mathrm{~cm})$ ploughing for rain fed parliament. 


\subsection{Selection of Crop Seed Variety}

A number of high yielding crop varieties have been developed for cultivation of different agricultural zone of Ethiopia. Some important varieties are drought tolerant, early matured, variety, seed which are resistant to ascochyta blight etc. (agronomy of field crop).

\section{Critical Stages of Crop Production}

The process of harvesting period to the marketing processes is harvesting seed, separation and storage of seed, and finally marketing. Harvesting period is the process in which matured crop can be harvested by different mechanisms. Combined machine seed separation is used for separation of seed from straw and finally stores in a sack. In the Ethiopia, transportation of the harvested yield for selling to the market is carried out by vehicle, animal or human.

\section{Crop Production Technologies}

In crop agriculture, using the modern system which encompasses biological and chemical technology is the fundamental for enhancement of land and crop productivity. These technologies include chemical fertilizers, selection of high yielding variety, use of irrigation systems, and soil fertility improvement. Adoption of new technology and being ready for change from the farmer's side is the policy interest in Ethiopia. Even though various crop agriculture technologies are considered as a principal, crop grower has different level of adoption and the application may take long time to be practiced by farmers for scaling up (Mottaleb, 2018).

\subsection{Chemical Fertilizers}

Inorganic fertilizer can easily available for plant to fulfill the nutrient requirement of the crop while it is applied in recommended time, plant growth stage, frequency of application, depth of fertilizer placement in the soil and the method of application should be coincide with the package of production made by researchers. African government has substantially increased use of cereal crop input in their own countries inspired by the Asian green revolution which was brought about by using high yielding seeds and fertilizer technologies. In Ethiopia integrated soil fertility management, organic and inorganic fertilizer was found to be most economically visible method to farmers as well as land productivity enhancement in the long term (Habte Werede et al., 2018).

In Ethiopia farmers are applying inorganic fertilizer haphazardly which could be below or above the recommendation of the nutrient required by specific cereal crop to nourish the total biomass of the plant. The government has a policy of fertilizer delivery to most farmers cultivating crop regardless of the water availability on the farm site of many areas in the country which has negative impact on production. When water deficit occur the crop do not respond to the applied fertilizers to the area. Hence, the policy of government should give priority for irrigation facility disseminations to farmers so that the recommended fertilizer used can be used efficiently in crop productivity and high return obtain through marketing of agricultural crops. The sustainable development of the economy of Ethiopia depends on the improvement of the livelihood of farmer which needs critical policy makers and follow-up till end users of the crop production rule designed by government.

The two major inorganic fertilizers that Ethiopian farmers are using currently are nitrogen $(\mathrm{N})$ and phosphorus $\left(\mathrm{P}_{2} \mathrm{O}_{5}\right)$ in the form of urea and DAP, respectively (Figure 5). The trend of fertilizer usage has been show substantial increase with the food crops yield increase. 


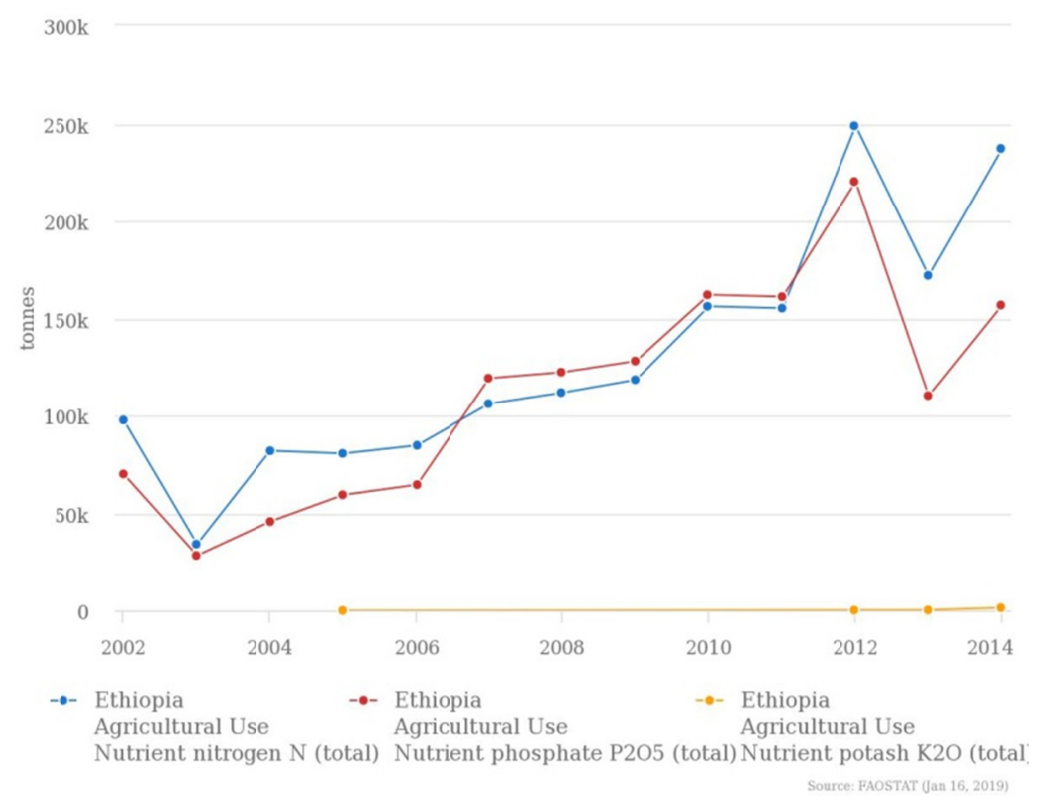

Figure 5. Ethiopia's nutrient use in agriculture

Source: FAOSTAT (January 16, 2019). Retrieved from http://www.fao.org/faostat/en/\#compare

\subsection{Improved Crop Seeds}

The improved crop seed has the traits like high yield, early maturity to escape from harsh climatic condition, resistant or tolerant to disease that reduce the cost of production, rich in nutrients to reduce the mortality of mother and child by providing strength for elders with vitamins, proteins and essential nutrients for human health from like biofortified crops. Moreover, it can provide multi climatic conditions suitable through its resistance to drought and heat in harsh environmental conditions. The production constraints are related to technical inputs; including improved seed availability, quality of improved varieties, fertilizer availability and ertilizer price, availability, and capital (Mesfin \& Zemedu, 2015). The challenges of farmers for improved crop seed use lack of knowledge and skill, less accessibility and inappropriately following of the packages of production recommended by researcher which has the potential to substantially increase cereal crop production in Ethiopia. For example, through adoption of high yield crop seeds with its best practices recommended by scientists as techniques of production in a quarter of the current crop area in Ethiopia, research reveals that crop grower could increase maize productivity over 60 percent and self-pollinated crop production over 30 percent (Alemu et al., 2010).

The use inorganic fertilizer and improved crop seed has substantial impacts on agriculture that help farmer to obtain high yield and better quality. The productivity and worth of crops enhanced through genetically manipulated seeds in selective breeding (Kintomo et al., 2008). Farming sector that is supplying improved seed should fulfill certain quality standards set by the national regulation which has a positive impact on agricultural productivity (Bishaw et al., 2012).

\subsection{Irrigation Facility as a Crop Production Technology}

The irrigation facility, the indicator of the advantage of irrigation, is inadequate in Ethiopia. Almost all farmers are dependent on rain for agricultural crop production which is irregular. Hence, availability of the irrigation facility is the fundamental to use irrigation water and produce sustainable crop yields throughout the year with the efficient use of available water in the country.

The majority of people in Ethiopia depend on agriculture and livestock for their livelihoods; however the frequency of droughts over the years has left many communities particularly vulnerable to climate change. The majority of people that depend on rain fed for crop agriculture production and left behind as a poor are resides in sub Saharan Africa which includes Ethiopia. (Burniy \& Naylov, 2012) stated that crop yield in sub Saharan African lowland is influenced by the variability of weather conditions in the area. The proper utilization and the reduction of wastages are critical in artificially supplying water resource through the irrigation system in order to obtain high crop yield and better seed quality. Agricultural crop growers can shift from seasonal cultivation through the usage of irrigation system which is important and plays a critical role in the makeup of soil moisture 
deficit. The research report argues that water resource management in agriculture is a critical contributor to the economic and social development of Ethiopia. If successful, irrigation in Ethiopia could represent a cornerstone of the agricultural development of the country, contributing up to ETB 140 billion to the economy and potentially moving up to 6 million households into food security (Awulachew et al., 2010).

The irrigation system distribution and usage in Ethiopia is very low and farmers are mostly relying on rain fed agriculture. Few rivers are under the use in pastoral and crop land area of Ethiopia (Figure 6).

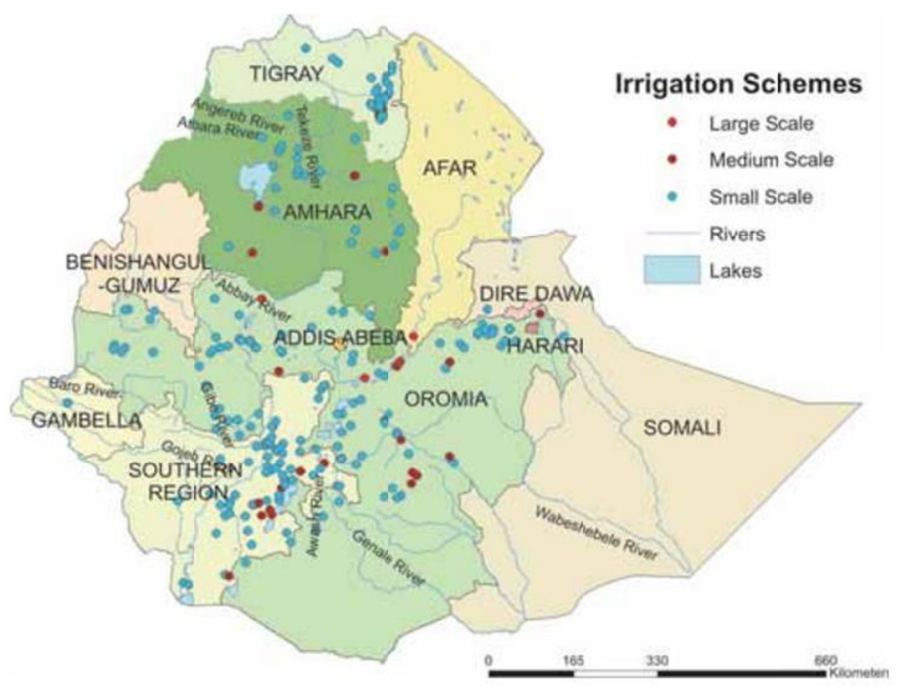

Figure 6. Existing irrigation schemes in various river basins in Ethiopia

Source: Awulachew et al. (2007b).

\subsection{Crop Rotation}

Crop rotation has advantage of reducing the influence of residual soil borne disease which was adapted to the genetic trait of the crops previously cultivated on the same land. Crop rotations have historically been driven by the need to build sufficient fertility through the crop sequence and to maintain control of antagonists (e.g., weeds, pests and diseases) (Knox et al., 2011). Rice and wheat rotation was practiced for many years and expected during the green revolution in South Asia (Yadaw et al., 2002).

\subsection{Intercropping}

Intercropping is the core agricultural technology to improve the life of the small land holder of farmers through the production of food crops for consumption and forage crops for the feed of animals. It has many advantages in improving the aeration of soil, suppressing invasive weed in the main field, managing air borne disease, improving the $\mathrm{CO}_{2}$ and $\mathrm{O}_{2}$ movement in the farm, production of livestock in intercropping of forage crops with the cereal crops.

Variegated agriculture systems are practices and landscapes that intentionally include official biodiversity at manifold spacial and/or transient scales in order to preserver ecosystem office that stipulate exact input to agronomy, such as soil fertility, pestilence and malady counteract, water use efficiency, and pollination (Kremen et al., 2012). Farmers grow mostly two or more crops on small land by using intercropping to feed their family and sustain life. Farmers use intercropping to the common beneficial of both capital and inferior riding crop in a manifold browse production system. Non legume intercropped cover crops can use soil N, while a legume intercrop can increase $\mathrm{N}$ in agricultural systems by biological $\mathrm{N}$ fixation. Intercropping also may be more efficient than mono-cropping in exploiting limited resources. Relay-planting the main crop and intercrop components so that resource demands (nutrients, water, sunlight, etc.) occur during different periods of the growing season can be effective means of minimizing inter specific competition. Intercropping systems often exhibits less crop damage associated with insect and plant pathogen attacks, and it provides weed control.

Intercropping is an age old practice of crop production. It is simple, inexpensive strategy and has been a potentially benefitted technology for increasing crop production. The present day intercropping is production oriented and requires a fairly good level of management and inputs. It has the advantage of improving water 
holding capacity of soil, efficient nutrient use of plant, multi-cropping, suppress unwanted plant and increase the yield. The most common advantage of intercropping is to produce a greater yield on a given piece of land by achieving more efficient use of the available growth resources that would otherwise not be utilized by each single crop grown alone (Lithourgidis et al., 2011).

\section{Comparing Conventional and Improved Technologies}

The most encouraging alternative innovation for expanding worldwide sustenance, feed and fiber creation is to consolidate the best of the old and the best of the new by coordinating the best traditional innovation and the best biotechnology application including sub-atomic, reproducing and the fuse of transgenic novel qualities. The enhanced yield creation coming about because of the cooperative energy of joining the best of old with the best of new including populace control, and enhanced sustenance, feed and fiber circulation (James, 2009). Technology in agriculture more, ahead at stud at stud's pace the long term. Technical progress also occurs with respect to society's ability to detect possible consequences to the environment of specific cereal crop production practices and farming system in agriculture (Batie, 1989).

\section{Major Constraints Faced by Ethiopian Agriculture}

Ethiopian agriculture has been experiencing different outer and inner issues. It has been stale because of poor execution because of components, for example, low asset use (the extent of developed land contrasted with the aggregate sum of land reasonable for farming and the measure of water accessible for water system is far underneath the limit and this finishes the segment to be rain nourished). Low innovation cultivating system (wooden furrow with bulls and sockles), over dependence unfertilized and underutilized strategies for soil and water preservation, wrong farming strategy, unseemly land residency approach, prudent corruption of potential or capable grounds. In Ethiopia there is increment in the joblessness rate because of expanding in the populace (Kibret, 1994). Yonas (2006) has additionally outlined the primary auxiliary imperatives for Ethiopian agriculture. These, among others, include: curve pro method of production and low take-up of the mechanical development which thus yield low dimensions of efficiency, debasement of land and other regular assets because of concentrated development and over touching, intermittent dry season, common hardship and political turmoil. Absence of successful arrangements administering such issues as a possession, land tangles, land fragmentation, and credit framework are extremely restricted and dismissed.

Ethiopia's national poverty in both rural and urban areas has shown a substantial decrease while the GDP per capita is grown from 129 USD to 794 USD which happen between the year of 1999/00 to 2015/2016 (Table 1). The agriculture sector is expected to undergo rapid increase and the Ethiopian economy will be transformed from poverty rank to middle income country within additional of about two decades.

Table 1. Poverty analysis study, national planning commission, September 2017

\begin{tabular}{llll}
\hline No. & Activities & Year & Yardstick \\
\hline 1 & Inflation rate & Nov. 2018 & $10.6 \%$ \\
2 & National poverty head count indices & $2010 / 2011$ & $29.6 \%$ \\
3 & Rural poverty head count indices & $2010 / 2011$ & $30.4 \%$ \\
4 & Urban poverty head count indices & $2010 / 2011$ & $25.7 \%$ \\
5 & National poverty head count indices & $2015 / 2016$ & $23.5 \%$ \\
6 & Rural poverty head count indices & $2015 / 2016$ & $25.6 \%$ \\
7 & Urban poverty head count indices & $2015 / 2016$ & $14.8 \%$ \\
8 & National income inequality using GINI coefficient & $2010 / 2011$ & 0.298 \\
9 & Rural income inequality using GINI coefficient & $2010 / 2011$ & 0.27 \\
10 & Urban income inequality using GINI coefficient & $2010 / 2011$ & 0.37 \\
11 & National income inequality using GINI coefficient & $2015 / 2016$ & 0.328 \\
12 & Rural income inequality using GINI coefficient & $2015 / 2016$ & 0.28 \\
13 & Urban income inequality using GINI coefficient & $2015 / 2016$ & 0.38 \\
14 & GDP per capita & $1999 / 00$ & 129 US Dollar \\
15 & GDP per capita & $2007 / 2008$ & 262 US Dollar \\
16 & GDP per capita & $2015 / 2016$ & 794 US Dollar \\
\hline
\end{tabular}

Source: FAOSTAT, January 2019. Retrieved from http://www.csa.gov.et/chioinfo-internal 


\section{Conclusion}

Ethiopia is one of the poorest countries in the world by most standards. The causes of poverty in Ethiopia are many, of which low productivity of the agricultural sector and the base of the national economy were recognized to be the major ones. During the past several years, a lot of efforts have been made to reduce poverty, though they could not lead to a remarkable outcome at grass root level. The government of Ethiopia both in the earlier development policies and the recent Growth and Transformation Plan (GTP) emphasized on the importance of the agricultural sector as an engine for the country's economic growth and poverty reduction.

None of the included financial factors effectively affected the allocative and monetary effectiveness of the homestead family units. Along these lines, the allocative and monetary wasteful aspects of the ranchers may have been represented by other regular and ecological components which were not caught in numerous looks into done previously. These elements incorporate, among others, arrive quality, climate, work quality, diseases and insect pest and invasive weed species pervasions. Government should structure arrangements to pull in homestead family units to build up co-agents for cooperating and sharing their insight among one another that could enhance effectiveness of the work and the market arrangement for agriculturists. The determinant factors, drivers of economic growth and poverty reduction in developing countries, for sustainable crop production are improved seeds, farm labor, irrigation system, intercropping, crop rotation, invasive weed control and forestation to reduce land loss. So far, mainly due to more expansive in terms of land area cultivated instead of increasing the productivity of the land by applying intensive management and technology, reduction of the crop yield is revealed in Ethiopia. Labor and crop production found out that farm labor is a major source of employment opportunity for the labor force in rural Ethiopia. However, it was noticed that labor productivity in rural Ethiopia has remained same in grain output. Capital in crop production is another yet mysterious issue in Ethiopia and few works have been dedicated to analyze the role it is proving to increase the overall production. However, it was recognized by different researcher to be an important factor that affects crop production. Technology and crop production have limited use of modern inputs in crop production in Ethiopia. This can be explained by relatively low level input use (fertilizer, pesticide, and improved seed), low level of irrigation, and soil degradation and soil erosion.

\section{Recommendation}

To enhance the intensive economy of farmers the prominent techniques, among other, are providing the theoretical and practical training to develop the skill and preparing the farmers field day to introduce new agricultural technology on the research site and model farmers land. Farmers' participatory research can give a chance for farmers to expose the agricultural problem revealed on farmland and sharing their experience with researchers and other stakeholders for better improvement of crop productivity. Increasing labor productivity, irrigation use, fertilizer use, intercropping for multidimensional crop advantage, and selection of improved crop seed are the most important agricultural technologies that farmers are expected to apply on their farmland for increasing crop productivity and lower the real costs.

Moreover, to empower and stabilize the livelihood of farmers through the improvement of agricultural crop production system and farmland productivity the following core points should be taken into account in Ethiopia.

\subsection{Government}

$>$ To promote a sound institutional development, that is flexible to change the subsistence agriculture into market oriented agriculture.

$>$ To support the incentive-based culture of innovation and creativity for agriculture development.

$>$ Harness the technological advances for agricultural development.

$>$ Reinforce rural development through provision of basic infrastructures.

> Sustain public investments in agricultural technology, research extension, irrigation facility and system, and market infrastructure.

Educate The Rural Farmers And Help To Update The Religious And Cultural Practice With The Modern Times. Ender and other factors that affect agricultural production should be considered and harnessed to sustain integrated development.

\subsection{Farmers}

$>$ Should adopt the use of new technology (fertilizer, pesticide, improved varieties) to increase their productivity and hence the production. 
$>$ Must join forces and work together in forms of cooperatives to be able to benefit from loans from banks and to promote the use of agricultural inputs

$>$ Be responsive to change.

\section{References}

Abberton, M., Batley, J., Bentley, A., Bryant, J., Cai, H., Cockram, J., ... Edwards, D. (2016). Global agricultural intensification during climate change: A role for genomics. Plant Biotechnology Journal, 14(4), 1095-1098. https://doi.org/10.1111/pbi.12467

Abdulai, H. (2016). Growth and yield of hybrid maize (Zea mays L.) varieties as affected by cowpea (Vigna unguiculata L.) growth types intercropping systems in Northern Ghana (Doctoral dissertation).

Adhikari, P., Araya, H., Aruna, G., Balamatti, A., Banerjee, S., Baskaran, P., ... Dhar, S. (2018). System of crop intensification for more productive, resource-conserving, climate-resilient, and sustainable agriculture: Experience with diverse crops in varying agroecologies. International Journal of Agricultural Sustainability, 16(1), 1-28. https://doi.org/10.1080/14735903.2017.1402504

Alemu, D., Rashid, S., \& Tripp, R. (2010). Seed system potential in Ethiopia. Constraints and opportunities for enhancing the seed sector. International Food Policy Research Institute, Addis Ababa/Washington, DC.

Asefa, S. (2011). Analysis of technical efficiency of crop producing smallholder farmers in Tigray, Ethiopia.

Awulachew, S. B, Erkossa, T., \& Namara, R. E. (2010). Irrigation potential in Ethiopia: Constraints and opportunities for enhancing the system.

Awulachew, S. B., Yilma, A. D., Loulseged, M., Loiskandl, W., Ayana, M., \& Alamirew, T. (2007). Water Resources and Irrigation Development in Ethiopia (p. 78). Colombo, Sri Lanka: International Water Management Institute.

Batie, S. S. (1989). Sustainable development: Challenges to the profession of agricultural economics. American Journal of Agricultural Economics, 71(5), 1083-1101. https://doi.org/10.2307/1243090

Bishaw, Z., Struik, P. C, \& Van Gastel, A. J. (2012). Farmers' seed sources and seed quality: 1. Physical and physiological quality. Journal of Crop Improvement, 26(5), 655-692. https://doi.org/10.1080/15427528. 2012.670695

Burney, J. A., \& Naylor, R. L. (2012). Smallholder irrigation as a poverty alleviation tool in sub-Saharan Africa. World Development, 40(1), 110-123. https://doi.org/10.1016/j.worlddev.2011.05.007

Chetty, R., \& Looney, A. (2006). Consumption smoothing and the welfare consequences of social insurance in developing economies. Journal of Public Economics, 90(12), 2351-2356. https://doi.org/10.1016/j.jpubeco. 2006.07.002

Crawford, E., Kelly, V., Jayne, T. S., \& Howard, J. (2003). Input use and market development in Sub-Saharan Africa: An overview. Food Policy, 28(4), 277-292. https://doi.org/10.1016/j.foodpol.2003.08.003

CSA (Central Statistical Agency). (2005). Ethiopia demographic and healthy survey 2005.

CSA (Central Statistical Agency). (2008). Summary and statically report of the 2007 population and housing Census.

CSA (Central Statistical Agency). (2014). Area and production of mean crops. Addis Abeba, Ethiopia.

De Rouw, A., \& Rajot, J. L. (2004). Soil organic matter, surface crusting and erosion in Sahelian farming systems based on manuring or fallowing. Agriculture, Ecosystems \& Environment, 104(2), 263-276. https://doi.org/10.1016/j.agee.2003.12.020

Fafchamps, M., \& Gubert, F. (2007). The formation of risk sharing networks. Journal of Development Economics, 83(2), 326-350. https://doi.org/10.1016/j.jdeveco.2006.05.005

FAO (Food and Agriculture Organization). (2018). Analysis of farming systems.

FAOSTAT (Food and Agricultural Organization of the United Nations). (2018). Compare Data. Retrieved from http://www.fao.org/faostat/en/\#compare

FAOSTAT (Food and Agricultural Organization Statistics). (2019). Retrieved from http://www.fao.org/faostat/ en/\#data/RFN

Fridman, E., \& Zamir, D. (2012). Next-generation education in crop genetics. Current Opinion in Plant Biology, 15(2), 218-223. https://doi.org/10.1016/j.pbi.2012.03.013 
Getahun, A. (1978). Agricultural systems in Ethiopia. Agricultural Systems, 3(4), 281-293. https://doi.org/ 10.1016/0308-521X(78)90014-8

Habte Werede, M., Smith, J. U., \& Boke Ambaye, S. (2018). Integrated soil fertility management for sustainable teff (Eragrostis tef) production in Halaba, Southern Ethiopia. Cogent Food \& Agriculture, 4(1), 1-9. https://doi.org/10.1080/23311932.2018.1519008

Hussain, I., \& Hanjra, M. A. (2004). Irrigation and poverty alleviation: Review of the empirical evidence. Irrigation and Drainage, 53(1), 1-5. https://doi.org/10.1002/ird.114

IFPRI (International Food Policy Research Institute). (2011). Food and Agriculture in Ethiopia: Progress and policy challenges (p. 31). https://doi.org/10.2499/9780812245295

James, C. (2009). Global Status of Commercialized Biotech/GM Crops. International Service for the Acquisition of Agribiotechnology Applications.

Kibret, H. (1994). Is the Ethiopian Birr Overvalued? A Preliminary Assessment and Policy Implication. The Ethiopian Economy: Problems of Adjustment.

Kindness, H., \& Gordon, A. (2001). Agricultural marketing in developing countries: The role of NGOs and CBOs. Natural Resources Institute Policy Series 13. Natural Resources Institute, Chatham Maritime, Kent, UK.

Kintomo, A. A., Akintoye, H. A., \& Alasiri, K. O. (2008). Role of legume fallow in intensified vegetable-based systems. Communications in Soil Science and Plant Analysis, 39(9-10), 1261-1268. https://doi.org/10.1080/ 00103620802003955.

Knox, O. G., Leake, A. R., Walker, R. L., Edwards, A. C., \& Watson, C. A. (2011). Revisiting the multiple benefits of historical crop rotations within contemporary UK agricultural systems. Journal of Sustainable Agriculture, 35(2), 163-179. https://doi.org/10.1080/10440046.2011.539128

Kremen, C., Iles, A., \& Bacon, C. (2012). Diversified farming systems: An agroecological, systems-based alternative to modern industrial agriculture. Ecology and Society, 17(4). https://doi.org/10.5751/ ES-05103-170444

Kuhn, A., Gaiser, T., \& Gandonou, E. (2010). Simulating the effects of tax exemptions on fertiliser use in Benin by linking biophysical and economic models. Agricultural Systems, 103(8), 509-520. https://doi.org/ 10.1016/j.agsy.2010.05.003

Lithourgidis, A. S., Dordas, C. A., Damalas, C. A., \& Vlachostergios, D. (2011). Annual intercrops: an alternative pathway for sustainable agriculture. Australian Journal of Crop Science, 5(4), 396.

Mesfin, A. H., \& Zemedu, L. (2015). Improved Rice Seed Production and Marketing: Challenges and Opportunities; the Case of Fogera District of Ethiopia. Journal of Agriculture and Environmental Sciences, 1(2), 1-21.

Mesfin, W. (1984). Rural vulnerability to famine in Ethiopia 1958-1977. Vicas, New Delhi.

Mottaleb, K. A. (2018). Perception and adoption of a new agricultural technology: Evidence from a developing country. Technology in Society, 55, 126-135. https://doi.org/10.1016/j.techsoc.2018.07.007

Narayan, P. K. (2004). Reformulating Critical Values for the Bounds F-Statistics Approach to Cointegration: An Application to the Tourism Demand Model for Fiji. Department of Economics, Discussion Papers No. 02/04. Monash University, Victoria, Australia.

Parsai, N., Vazin, F., \& Hassanzadeh, M. (2016). The Effect of Irrigation Intervals Scheduling and Nitrogen and Zinc Content on Wheat Yield and Yield Components in Drought Stress. Cercetari Agronomice in Moldova, 49(4), 15-26. https://doi.org/10.1515/cerce-2016-0032

Pingali, P. (2007). Agricultural growth and economic development: A view through the globalization lens. Agricultural Economics, 37, 1-2. https://doi.org/10.1111/j.1574-0862.2007.00231.x

Pratt, C. F., Constantine, K. L., \& Murphy, S.T. (2017). Economic impacts of invasive alien species on African smallholder livelihoods. Global Food Security, 14, 31-37. https://doi.org/10.1016/j.gfs.2017.01.011

Pretty, J., Benton, T. G., Bharucha, Z. P., Dicks, L.V., Flora, C. B., Godfray, H. C., ... Pierzynski, G. (2018). Global assessment of agricultural system redesign for sustainable intensification. Nature Sustainability, 1(8), 441. https://doi.org/10.1038/s41893-018-0114-0 
Rakesh, K., \& Rajkumar, J. (2018). Water requirements and irrigation scheduling of maize in Northern Gangetic plains. International Journal of Agricultural Engineering, 11(1), 210-215. https://doi.org/10.15740/ HAS/IJAE/11.1/210-215

Rezene, F. (2006). Challenges and potential of P. juliflora. In R. Fessehaie, A. Tekelemariam, K. A. M. Dawd, \& S. Ahemed (Eds.), Alien invasive weed and insect pest: Management and control option (pp. 53-63). Second National Workshop on AIS.

Sánchez-Toledano, B., Kallas, Z., Palmeros Rojas, O., \& Gil, J. (2018). Determinant Factors of the Adoption of Improved Maize Seeds in Southern Mexico: A Survival Analysis Approach. Sustainability, 10(10), 3543. https://doi.org/10.3390/su10103543

Se, A. S., Dorosh, P., \& Gemessa, S. A. (2013). Crop production in Ethiopia: Regional patterns and trends. Food and agriculture in Ethiopia: Progress and policy challenges. https://doi.org/10.9783/9780812208610

Tuyen, T. Q., Lim, S., Cameron, M. P., \& Huong, V. V. (2014). Farmland loss and livelihood outcomes: A microeconometric analysis of household surveys in Vietnam. Journal of the Asia Pacific Economy, 19(3), 423-444. https://doi.org/10.1080/13547860.2014.908539

UNPF (United Nations Population Fund). (2017). National accounts, UN Population Fund, UNDP data, FAOSTAT and OECD. Conversions done using World Bank annual data on currency conversion factors.

Ushamutu. (2012). Unit 2c. Business, Technology.

Yadav, R. L., Dwivedi, B. S., \& Pandey, P. S. (2000). Rice-wheat cropping system: Assessment of sustainability under green manuring and chemical fertilizer inputs. Field Crops Research, 65(1), 15-30. https://doi.org/ 10.1016/S0378-4290(99)00066-0

Yesuf, M., \& Bluffstone, R. A. (2009). Poverty, risk aversion, and path dependence in low-income countries: Experimental evidence from Ethiopia. American Journal of Agricultural Economics, 91(4), 1022-1037. https://doi.org/10.1111/j.1467-8276.2009.01307.x

Yonas, K. (2006). Post-1991 Agricultural Polices: The Role of National Extension Program in Addressing the Problem of Food Security. In A. Alexander, B. Kasahun, \& K. Yonas (Eds.), Ethiopia: Politics, Policy Making and Rural Development. Department of PSIR, AAU, Addis Ababa.

\section{Copyrights}

Copyright for this article is retained by the author(s), with first publication rights granted to the journal.

This is an open-access article distributed under the terms and conditions of the Creative Commons Attribution license (http://creativecommons.org/licenses/by/4.0/). 